管球振角を $15^{\circ}$ ，撮影体位は腹卧位 $20^{\circ}$ とした。これら の条件の元に実際に患者を撮影し, 胆のう胆管の示現位 置を調べてみた。

デー夕を元に腹厚及び, 腹臥位第 2 斜位での腹厚を測 って, 胆のう䏣管等の位置を次の式で推定するととが出 来ました。

$\begin{array}{ll}\text { 腹厚 } 18 \mathrm{~cm} \text { 末満 } & \mathrm{D} \fallingdotseq 1 / 2 \mathrm{~T}-2 \\ 18 \mathrm{~cm} \text { 以上 } 21 \mathrm{~cm} \text { 未澫 } & \mathrm{D} \fallingdotseq 1 / 2 \mathrm{~T} \\ 21 \mathrm{~cm} \text { 以上 } & \mathrm{D} \fallingdotseq 1 / 2 \mathrm{~T}+2\end{array}$

$D$ ：胆管示現位置， $T$ ：腹臥位第 2 斜位腹厚,

これにより，ほぼ満足する結果が得られたので報告い たします。

\section{4. 胸部断層，楕円軌道の制限曝射について}

米沢市立病院放射線科

○林洋 五十嵐 繁
木村 義䖉

昭和46年当院に，シーメンス社製の多軌道胘層装䁂， ムルチプラニグラフ 2 が設備され臉部断層撮影に楕円軌 道を使用しましたが，截断面より離れた，助骨，鎖骨の 陰影があらわれ障書之なるので, 解決すべく, 福島医大 松川教授の円軌道撰択曝射断層撮影の論文よりヒントを 得て, 電気的に軌道の改良をして良い結果を得た。

上下 $70^{\circ}$ つつの制限軌道により，長軸に直角に近い肋 骨のボケ残像による干造陰影は除去され，円の撰択暴射 の理論と一致していた.

截面の鮮鋭度については，X線の出ない方向がわるく

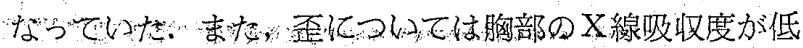
いので，臨床的にめだたない。

\section{（穈長集約）矢嶋 克已（秋田赤十字病院）}

撮影 I は発表演題 4 題, 内容は, 脳, 胃, 䏣のう, 胸 部の 4 分野に亘る撮影方法の検討が主題であった。

我々が，日常業務で一般的に取り扱う分野でああり， 夫々に参考すべき所が多々あり，発表者の努力に敬意を 表したい.

以下，個々、概略を列記する。

1 原，弘前大学長内等の定位脳手術におけるX線撮影 の検討は，脳外科部門の適確，精密度を要求される撮影 であるが，固定具と FFD の思い切った延長等で，目的 部0.5 mm 以下に抽さる事力゙出来た. FFD 延長に伴 う条件の補正は $\mathrm{kVp}$ を上げる事よりも，固定が確実な ので, mAs 值の調整で contrast の良い写真を作ってい 万.

2 矦の加藤胃腸科, 木村, 平鹿総合病院, 大台等の, 我々の胃前壁レリーフ造影法は, 胃前壁レリーフ像の適
切な描出方法として, 投与造影剤の量, 体位変換, 空気 含有量等の要素を把握しながら，364 例中，有効なもの， 287例と，優秀な成績であった。技師が贯撮影にあたる 機会は，間接部門を除けば，まだ，稀少であると思うが， 医師と共同で，少校数で有效な読影をする術式を開発す る努力はしなければいけないと考える。

3 席，公立学校共済東北中央病院，长司等の胆のう造 影における断層撮影の検討は，断層撮影の被懪線量の多 い事からあ；正確な位置確認により，最少枚数（出来れ ば多層カセッテ）で撮影する事が望ましい.その為の位 置確認の工夫がなされていた. 解剖学的に, 腹壁厚 3 $5 \mathrm{~cm}$, 胆管部 $6 \sim 8 \mathrm{~cm}$ 知り，同一体位がとれるよ うに補助具（角度 $45^{\circ}$ の台）を使用している。断層の振 角による有效裁断面は， $32^{\circ}$ で $5 \mathrm{~mm} ， 17^{\circ}$ で $10 \mathrm{~mm}$ であ つた。

4 席, 米沢市妾病院, 林等の胸部断層楕凸轨道の制限 曝射については，装置のX線曝射回路を改良し，楕円軌 道の全暴射と, 長円部分の間欠曝射が出来るようにして, 両者の像の検討を行った。雨者共に大差のない像が得ら れ，被曝軽減の上から向有効であった。

\section{5. 脳血管連続立体撮影に於けるリスホルムブレンデ の検討}

山形県立中央病院放射線科

○峯田 信彦 佐藤 輝郎
軽部 邦勝

ステレオ撮影装置の設置に伴なり，各種血管連続立体 撮影を行ってきたが，脳血管連続撮影においては，斜入 角での撮影像を正面像とするためりスホルムブレンデに よるケラレが生じ，実用に至らないため，200の斜入角 を持つリスホルムブレンデを製作してもらい CAGを行 ったととろ，眼窩と血管像为重複し，診断に支障をきた すので, AOT 自体に0〜150まで角度をとれるように

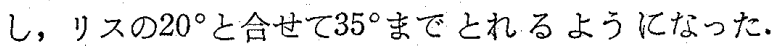
AOTのリス上に頭を乗せるとき，全体が水平になるよ うに，斜めの台を置いた。この台による像の拡大は問題 にならないくらい小さい。わずかリス上より頭頂部で $2 \mathrm{~cm}$ 離れるだけである.

\section{6. 両側同時逆行性上腕動脈造影剂注入による椎骨動 脈撮影}

秋田県立脳血管研究センタ一放射線科
○佐藤 昌晃 相沢 沗夫
小野寺 洋 蜂谷 武憲
管 幹雄 左司 安明
佐々木信夫

